\title{
"Look who is laughing now": Physical capital, boxing, and the prevention of repeat victimisation
}

OÑATI SOCiO-Legal Series, Volume 11 Issue 5 (2021), 1095-1113: YOUTH VIOLENCE: DeESCALATION STRATEGIES AND SOCIO-LEGAL RESPONSES

DOI LINK: HTTPS://DOI.ORG/10.35295/OSLS.IISL/0000-0000-0000-1171

RECEIVED 24 JANUARY 2020, ACCEPTED 20 JULY 2020

\section{DEBORAH JUMP*}

\section{Abstract}

This paper's aim is to further current thinking around young men's perceptions and understanding of violence, and the use of boxing as a vehicle in the prevention of repeat victimization. The focus is on the use of bodily or physical capital, and the ways in which men draw upon this resource to ward off attacks to identity and psyches, especially those perceived as disrespectful. It will draw on data from The Criminology of Boxing, Violence and Desistance (Jump 2020), and present overarching ideas from Tyrone, a psychosocial case study highlighting the underpinning theory and its development. This paper disrupts common discourses that argue that boxing is a panacea for all violence, and thus presents more subjective nuanced accounts of men's lives in the gym, and the streets. In using the term "physical capital", I employ Wacquant's (1995) theory, and suggest that boxers not only use their body as a "form of capital" (p. 65), but that the physical capital accrued through the corporeal praxis of boxing, is actually a way to disavow prior victimization, and invest in the prevention of repeated traumatic scenarios.

\section{Key words}

Boxing; violence; psychosocial

\section{Resumen}

El objetivo de este artículo es ayudar al avance de la reflexión sobre las percepciones y concepciones de los hombres jóvenes sobre la violencia, y el uso del boxeo como vehículo para prevenir la victimización reiterada. La atención prioritaria es

\footnotetext{
${ }^{*}$ Deborah Jump is Senior Lecturer in Criminology at the Manchester Metropolitan University. She has over fifteen years' experience of working in youth justice as both a practitioner and service manager. She is the Head of Youth Justice at the Manchester Centre for Youth Studies and was previously the recipient of a Winston Churchill Memorial Fund evaluating the impact of sporting programmes on communities in the USA. Contact details: Manchester Metropolitan University, Dept of Sociology, Geoffrey Manton Building, M15 6LL. Email address: d.jump@mmu.ac.uk
} 
sobre el uso del capital corporal o físico, y cómo los hombres recurren a él para prevenir ataques a la identidad o a la psique, sobre todo aquellos percibidos como irrespetuosos. Se parte de datos de The Criminology of Boxing, Violence and Desistance (Jump 2020), y se presentan ideas generales de Tyrone, un estudio de caso psicosocial que arroja luz sobre la teoría subyacente y su desarrollo. El artículo rompe con el discurso común de que el boxeo es la panacea para toda violencia, y así presenta testimonios matizados más subjetivos de las vidas de hombres en el gimnasio y en las calles. Al usar el término "capital físico", utilizo la teoría de Wacquant (1995) y sugiero que los boxeadores no sólo usan su cuerpo como una "forma de capital" (p. 65), sino que el capital físico adquirido a través de la praxis corporal del boxeo es en realidad una forma de negar victimizaciones previas y de invertir en la prevención de escenarios traumáticos reiterados.

\section{Palabras clave}

Boxeo; violencia; psicosocial 


\section{Table of contents}

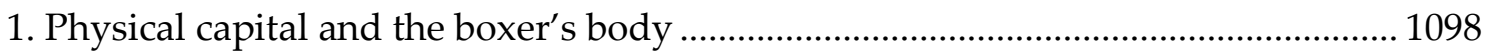

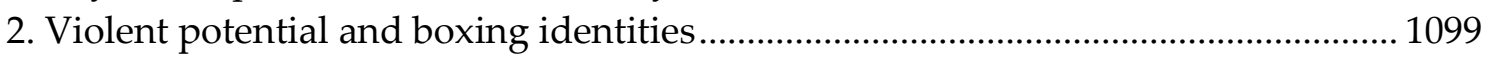

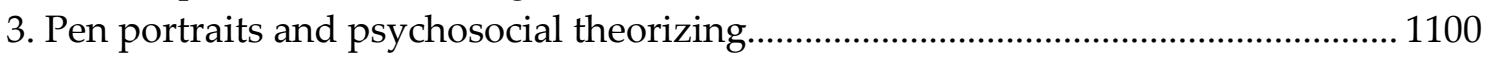

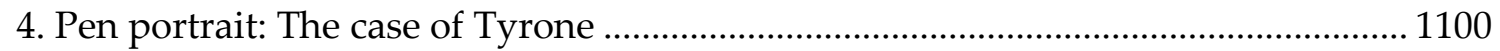

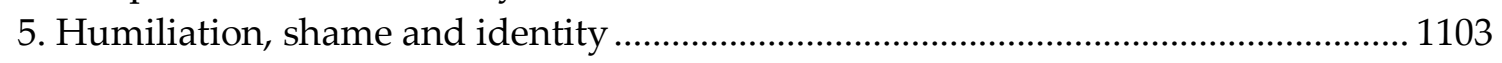

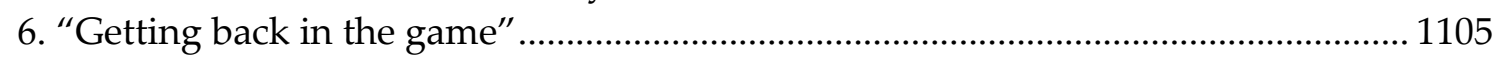

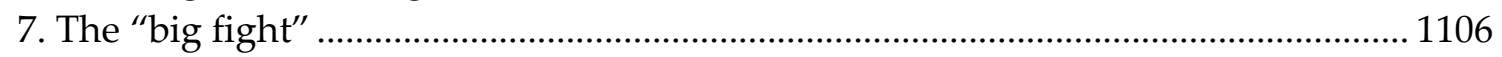

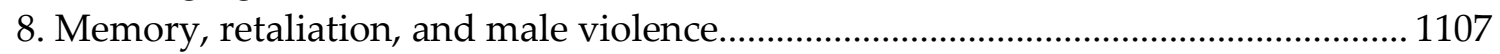

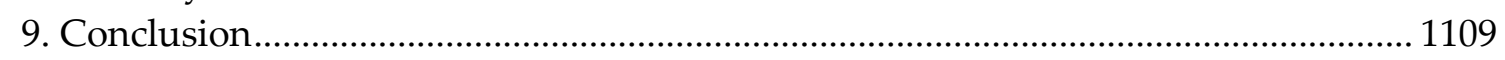

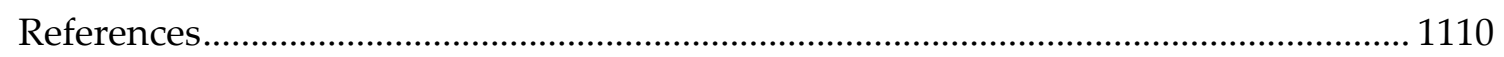




\section{Physical capital and the boxer's body}

A boxer's identity is everything to him. The pseudonyms given, and carnivalesque names we often hear in the homosocial world of boxing, contribute towards this successful identity as man of somatic power and violent potential. One only has to flick through boxing's historical bounty and admire names such as The Greatest, Hitman and Iron. Indeed, these are often without irony, and give credence to the latent power that these men of pugilism possess. As Theberge $(1991,124)$ writes: "Successful images require successful bodies, which have been trained, disciplined and orchestrated to enhance our personal value". More specifically, this personal value is not homeostatic, and therefore has to be constantly regulated, updated, and fine-tuned. Moreover, it has to be converted into external recognition, usually in the form of income streams, titles, and belts. Joyce Carol Oates $(1987,5)$ writes: "[L]ike a dancer, a boxer 'is' his body, and totally identified with it", and without this communion, boxers would not be able to accrue what Wacquant $(1995,66)$ refers to as "pugilistic capital".

"Pugilistic capital" (ibid.) as a concept builds upon Bourdieu's (1986, 241) ideas of accumulated labour, whereby, labour in its materialized form or embodied form, enables "appropriation of social energy in the form of reified or living labour" (ibid.). Put more simply, the body becomes the product we sell and the capital we accrue, and is therefore reified through money, contracts, and social standing. In Marxian terms, the body becomes the boxer's means of production. As one participant in this study nicely illustrated: "It's all I've got, this boxing lark, can't do anything else, left school with nothing, and boxing is my only option now" (Ricky, 20-year-old professional boxer). The body in its centrality becomes the asset by which men make their money, and in some respects, also accrue their social standing. Moreover, the body becomes men's armour as well as a money-making organism, and thus allows for them to not only invest in the potential capital, but further sequester feelings of vulnerability behind a spectacular somatic façade.

Sam Fussell (1991), in his book Muscle, captures the above argument perfectly, when he describes how the insecurity fueled by uncertainty at moving to a new city besieged him with doubt about his masculine potential and his ability to withstand the vicissitudes of a big city like New York. To overcome this fear, and self-doubt, Fussell invests in the sport of bodybuilding, and in his words, "erect a human fortress" to take refuge in. He discussed how he builds a muscular suit of armour as a means of self-defense; a method by which he could deny intimacy and disavow vulnerability. The anthropometrics and management of the self through the body also lend themselves to more structural constructionist debates; debates that see the body as both simultaneously biological and social (Bourdieu 1984, Shilling 1993, Matthews 2014). Each of these theories view the body as an unfinished project and argue that the body is a landscape to mold and construct, and thus informs and restricts action choices. Therefore, bodily projects such as boxing and bodybuilding - ones that actively transform the body - emphasize changing relationships between body, self, and society. Brown (1999), in his work into bodybuilding, draws on seminal works by Klein (1986) and Wacquant (1995) to develop this very idea. Brown suggests that men gain a sense of self through their embodiment, and more importantly, the ways in which they can accomplish masculinity par excellence through the pursuit of muscle and size. Furthermore, bodies are integral parts of the 
social construction of gender, and (Bridges 2009), therefore develops the idea of "gender capital", to highlight the juxtaposition between bodies and their performative nature. According to Bridges $(2009,92)$ and his work around bodybuilding, gender capital refers to the "knowledge, resources and aspects of identity available - within a given context - that permit access to regime-specific gendered identities". Put simply, gender capital varies significantly by context, and allows for individuals to negotiate different aspects of themselves dependent on the gender performance required within that context. Sporting bodies are not the only source of gender capital, but they are an important source, and within the context of boxing, they most certainly align with Connell's (1998) theorizing around the gender order and hegemonic masculinity, as it has been suggested that "sport is the leader definer of masculinity in mass culture" (Connell 1995, 54).

The similarities to boxing here are not lost, and within this paper, I will buttress these very ideas. It is also my intention to expand these arguments into a more criminological debate, and argue that the accruement of physical capital, and indeed, gender capital, are part of a strategy to defend against repeat victimization. I will do this by presenting data that suggests that the appeal of boxing, and its monastic drudgery, are more than making money through the appropriation of living labour as Bourdieu and Wacquant first suggest. I argue that the investment in the praxis of boxing is often a way to additionally create "violent potential" (Hobbs 1995) and ward off any attacks to both the physical and psychic sense of self.

\section{Violent potential and boxing identities}

Hobbs (1995) describes violent potential as a credible threat by which men are favourably judged. In other words, the more potential for violence, the more revered you become in the eyes of other men. According to Winlow (2001), a subliminal hierarchy is formed among certain groups of men, especially those that are attuned to incidences of violence. Such individuals will therefore place themselves in a pecking order and use their knowledge of violence about others as yardsticks for competition. This is an important point, as the inherent discourse of the boxing gym lends itself to this very idea. Boxing, and boxers' identities, are aligned with the very idea of violent potential, and this is evidenced not only in the day to day investments of physical capital, but in the carnival nature of pre-fight "weigh-ins", were each man stares down his opponent to demonstrate his capacity for destruction and violence. Boxing gyms are based on this premise, evidenced by the fact that it is one of the few sports in which the annihilation of another by violent means is its sole purpose. ${ }^{1}$ Wiley $(1989,227)$ calls boxing "assault and battery with deadly weapons called the fists of man"; and this assault can leave irreversible damage on one's own body and that of competitors. As one of my participants in this study suggested "it's the only professional sport where you have an ambulance and a doctor on standby" (Roger, 63-year-old retired professional and coach). In addition, the very nature of the sport itself is violent expectation, which, as Roger further stated: "[W]atching a boxing match and not waiting for a knockout is like watching football and not expecting a goal". Boxing is violence, albeit legitimized, but nonetheless, violence. Therefore, what is about boxing that is appealing to young men? As Jonny, the 18-year-old professional fighter in the gym states, "[W]hat does it

\footnotetext{
${ }^{1}$ Apart from MMA, which is also a masculine validating contact sport.
} 
say about a person who chooses to get hit for fun?" To help answer these questions, I present the case of Tyrone; a pen portrait of a man versed in the world of boxing, and also a man versed in the language of violence and trauma.

\section{Pen portraits and psychosocial theorizing}

Pen portraits are narrative accounts of individuals' life stories, and commonly used in psychoanalytical texts. I consider my work to be grounded in the psychosocial tradition, and psychosocial criminology often uses $\mathrm{N}=1$ to explore how the psychological and social constitute each other, without collapsing one into the other (Gadd 2004, Maruna and Matravers 2007). Using these life story approaches allows for psyches to be unveiled, as well as engaging with issues of social structure, power and discourse, commonly associated with structural reasonings and more critical criminological theorists. Jefferson (2002) suggests it is naïve to presume that certain segments of the population, especially the disenfranchised, share a common outlook because of their structural positioning; that is, that people offend because they have experienced "strain" (Merton 1938), or that they have inherited poor self-control due to problem families. Accordingly, we need to be more creative and look more closely at the inter-subjective - the interplay between the individual's psyche and unconscious motivations - to the social indices of power and discourse.

While not always considered scientific, psychosocial case studies are increasingly understood as representative of personal outlooks and theories of reality, not reality itself. Based on personal historical fact, the self-narrative is seen to be an imaginative rendering through which the past is reconstructed, edited, and embellished in order to create a coherent plot and theme of one's life. As McAdams $(1993,496)$ writes: "[T]hey hold psychological truths", and these representations of individual truths can and do shape future action, as one seeks to behave in ways that correspond to our personal myths. All this considered, narrative analysis can inform our understanding of cultural influence and the underlying psychic responses to issues of socio-structural impediments, while empathically bearing witness to the story-teller and their personal struggles.

\section{Pen portrait: The case of Tyrone}

Born in 1969 on a council estate in England, Tyrone described how he grew up in "a very hard working-class area". Raised by his father who served in the Marines, and also his mum, a housewife, Tyrone referred to his local area as: "racist, and where no-one had anything". Being an only child, and an "overweight kid", Tyrone had not even considered boxing until his cousin convinced him to go to the local gym. Knowing he needed to lose weight but frightened of entering the gym where "everyone thinks they're dead hard", Tyrone showed initial reluctance and did not attend. However, after being assured that the coach would look after him, Tyrone walked down to the local boxing club and has "never left since":

I walked into the gym, and my coach was there, he has been at the gym for 55 years now, and we basically just developed a relationship from there, I became part of the family. 
Tyrone began to attend the boxing club on a regular basis, as he saw the gym as "one big family, a place where you feel safe and the coach looks after you, and you make friends". Prior to enrolling, Tyrone had begun to over-eat, indeed, feeling "anxious most of the time" Tyrone comfort ate for "safety". This resulted in him being bullied at school, as he further disclosed that he felt "pretty frightened most of the time". As a result, Tyrone told me that he sought sanctuary in food and believed then that he also "found safety in it". I therefore asked why he felt the need to "feel safe", and he began to tell me how it was for him growing up in a military household; with a dad who was in the Marines.

DJ: You mentioned the gym was like 'family'; explain that more to me.

Tyrone: When I was at home, I had to be a soldier. I'd say my dad didn't have a son he had a soldier. I got love off my mum, but my dad was in charge and that was just the way it was. So, what I got from the gym was men who knew how to fight, knew how to look after themselves, but could let that 'toughness' be something else. Whereas my dad, he served 22 years in the Marines. 'Tough love' - he's just that kind of man.

When referring to this "tough love", Tyrone discussed how his father would wake him up every morning at 5 am to go running, and abstain from any affectionate embraces with his son, turning his back on Tyrone when he was crying and so forth. Tyrone described his early childhood as "miserable", and how he dreaded his dad coming home on leave as he knew that the "military regime would start", and Tyrone being "punished for the slightest thing". Attributing it to "the stress", Tyrone began to gain weight in the midst of "all the military training and chores", and took solace in food as a form of gaining some kind of autonomy and control. Accordingly, Tyrone was taunted by local youths for being "the fat kid", and would therefore hide in his room away from his father, and the local children.

Reluctant at first, but inspired by his cousin, Tyrone joined the boxing gym at 13 years old. Unlike the atmosphere at home, Tyrone referred to the gym as a place where he "could be himself". Describing the coach as "all smiles, no snarls", Tyrone felt safe around him, as he was a "beautiful man, who knew what to say to you to make you feel better about yourself". Originally attending the gym to lose weight, Tyrone found a love for both boxing and his coach, and discovered that he was "surprisingly good at it". As Tyrone started to lose weight his confidence grew. Being talented at the sport, and under the coach's watchful eye, Tyrone began to enter local amateur competitions. Triumphant in these competitions and with many a trophy in his possession, Tyrone began to slowly feel accepted. Being "brought on" by the coach, Tyrone described how he felt looked after and cared for:

He just looked after me; he gave me a hug, spoke to me like an adult and cared for me.

When suggesting that this was the role of a father, Tyrone became upset, and began to talk of how he would spend time at his grandparents to avoid going home. Living close to the family home, Tyrone would regularly go straight to his grandparents' house after school and wait until his dad had left the house before returning himself. Referring to himself as a "mummy's boy", Tyrone would enjoy time at the house in the company of his mother, but was avoidant of his father's chores and afraid of his "military style punishments". I therefore asked Tyrone how his father responded to the boxing, and it seemed that his father endorsed the discipline and aggression of the sport, but never encouraged Tyrone's hobbies or participated in Tyrone's life outside the home: 
He liked me boxing, because it was a 'manly' sport, but he never came to any of my fights, never once. I don't know why. I guess it was part of his 'tough love'. With him it was never good enough.

Tyrone described his father's "tough love" as instrumental in his boxing success, but seemed upset that his father never endorsed it. Arguably desperate for some acknowledgement from his father, Tyrone signed up for the Marines at sixteen. This was an interesting point, as it seemed that Tyrone used aggressive "manly" pursuits to try and forge a link with his father. Yet, at the same time I sensed that Tyrone was resentful of him, and would rather spend time with other family members. Regardless, Tyrone enlisted in the army for two years, and enjoyed the structure and discipline of the army, as it was a regime he was used to with the boxing training, and the family home. However, after finishing his term, and with a reluctance to go overseas and fight, Tyrone dropped out of the Marines, much to the disappointment of his father:

I spent 2 years in there, the boxing and the fitness set me in good stead for that, and it gave me the confidence, you know, so I was good in the Marines. But I didn't want to go to Northern Ireland, particularly in the 1980s, so I came out. My dad wasn't happy, as he was a Sergeant Major at the time.

After leaving the military, Tyrone returned to boxing; seeking out his old gym and trainer. Without employment, but with a desire to turn professional, Tyrone took "some time out" to plan his future. Boosted by his military training and the confidence accrued through winning titles at an amateur level, Tyrone decided to earn some money through bare-knuckle fighting at military camps in the Middle East. With the help of his cousin - who originally encouraged Tyrone to attend the boxing club - they travelled to the Middle East to "fight and make a fortune".

A year later Tyrone returns home with "no money to show for it", but a "reputation as someone not to fuck with". Having spent the time in the Middle East before planning to turn professional, Tyrone had had time to construct an identity as "someone not to fuck with". He stated that he would not instigate violence, but would "fuck anyone up who wanted to have a pop at him", and that he felt sorry for anyone who tried to bully him again. Yet, he still viewed himself as a "good lad with a heart of gold". Nonetheless, it was with this new-found identity and professed "heart of gold" that led Tyrone to intervene in a fight six days after his return from the Middle East. As a result of this decision he found himself in a wheelchair for the next six months:

After six days of being back in [area] I heard a girl scream, I just heard screams. I was with my girlfriend at the time, and I ran across the road and there was a large group of lads, I ran into the middle saying: 'What's happening? What's the problem like?' They then said: 'No problem here mate', and as I turned to walk away one of them hit me over the back of the head with a wheel brace.

It further transpired that his girlfriend also lost a kidney that night as she desperately clung to Tyrone's head to stop the bleeding. The group of lads responsible for the attack proceeded to kick Tyrone's girlfriend until an ambulance arrived. I asked Tyrone what possessed him to run over to a gang of lads as a solo intervener and he could not fathom it himself:

DJ: What possessed you to run over to a gang of lads? 
Tyrone: I don't know, to this day I don't know. A sense of what's right I guess, I didn't think at the time, the military training, the boxing training... I just wanted to help.

It is arguable that in the presence of his girlfriend and his reconfigured identity as "someone not to fuck with", Tyrone felt equipped to intervene. Being desperate to cling onto his newfound acceptance as the local hard lad and reformed "fat kid", Tyrone ran over to a group of men armed with just a sense of confidence and bravado. However, Tyrone's father, on hearing that his son had been attacked proceeded to gather "some army boys together" and "go looking for the cunts", yet, on Tyrone's insistence his dad never retaliated. Tyrone knew his dad "had weaponry", as did "half the street", and Tyrone was worried about the escalation of violence and the "potential comeback on the family". Therefore, for Tyrone, it seemed that his identity as the local hard lad was finished as he admittedly gave up the mantle after the attack:

Tyrone: My family wanted to sort it out, but I said I wasn't interested. What happened to me happened, and in a daft way, I'm glad it did.

DJ: Why were you glad?

Tyrone: Because the life I have had since has been good, I think 'yeah' I'm glad that happened. It sounds daft but it changed the way I was going - I was a dickhead, I had arrogance, I was a bighead and maybe if I hadn't had that arrogance, then maybe I wouldn't have gone over to a gang of lads thinking I was 'all that'.

This was an interesting point in Tyrone's narrative, as previously he stated that he "didn't know" why he ran over to a gang of men, whereas in the above extract we can see that it was Tyrone's own expectations of himself - "thinking I was all that" - that contributed to his decision to run over. Not entirely comfortable with this identity, but a somewhat graduation from the local "fat kid", and bolstered with enough physical capital and violent potential, Tyrone made a decision that would ultimately change his life.

Tyrone disclosed that he felt compelled to defend his status after the attack, plus his father was enraged about his own reputation, feeling that violent retaliation was the correct rectification for the assault on his son. Tyrone, however, when faced with the reality of repercussive action, no longer wanted to participate, yet, in masculine cultures, the defence of one's status or honour is paramount to maintaining an identity (Blok 1981, Katz 1988, Toch 1992, Anderson 1999). Hence, being defeated in a physical altercation can undermine one's sense of status, and the admiration that Tyrone had recently accrued started to dissipate quite quickly after the attack. In Tyrone's mind, he plunged back into feelings of worthlessness, brought on by shame and humiliation at having been assaulted without an avenue for recompense. This lack of retaliation therefore resulted in Tyrone feeling like he was the "bullied fat kid again".

\section{Humiliation, shame and identity}

Tyrone, stripped of his newfound status and released from hospital in a wheelchair, referred to his actions in a shameful way; discussing how he felt he "lost everything overnight":

I wouldn't have changed it, I wouldn't have changed what happened, just my pride took a kicking that's all. 
After the attack, Tyrone described how he would be left at home in a wheelchair with just a bedpan, his girlfriend having now left, as his plan to turn professional became highly unlikely. As a result, Tyrone described feeling suicidal. This is not uncommon amongst boxers who have suffered terrible defeats, particularly when dreams of success are also shattered. ${ }^{2}$ Indeed, the loss of a fight for some men can be classified as such a humiliating emasculating experience, that the psychological pain can be so powerful that some men would rather "die trying" than admit defeat (Winlow and Hall 2009). This is particularly acute for working class men who have experienced violence from an early age (ibid.) or what Hall (1997) refers to as a "visceral habitus": an environment in which men unify in their labour and reputation, especially through visceral commodities such as heavy industry and military.

Seen in this light, specific elements of masculine working-class life (Sennett and Cobb 1973, Ellis et al. 2017) can arguably point towards inherent feelings of shame associated with certain codes; codes that place high value on physical violence as a retaliation mechanism (Anderson 1999). Winlow and Hall $(2009,43)$ argue that "men who carry deeply ingrained visceral dispositions that are the products of socialisation within microclimates of insecurity, aggression, and domination, often come to value violence as a viable solution to a problem". And as Robins and Cohen (1978) have also argued, working class men are more likely to be socialised within a framework of cultural capital that places violence central to the concept of the male self. As a result, it is often employed as a personal resource that informs and advises social interaction and performance. According to Young (2003) individuals that are insecure in their identity are believed to use aggression as a compensatory tool designed to boost their ego and/or social status, as individuals that are insecure and doubtful of their own moral worth hold negative views of themselves and others. This negativity can lead to feelings of shame and humiliation for some men, particularly when raised in a climate of aggression and domination with strong cultural codes emphasising revenge (Crocker et al. 2004, Butler 2008). Accordingly, violence and violent potential are often viewed as a "cultural expectation" especially for working class men, as it is seen as a way to sublimate shame and overcome humiliating experiences, both past and present (Wolfgang 1959, Toch 1992, Scheff 2000, Winlow and Hall 2009, Ellis et al. 2017). Thus, for men like Tyrone, the essence of humiliation can become inflamed, as he now found himself wheelchair bound, and devoid of a promising boxing career. Moreover, Tyrone's weight "ballooned", as he found himself unable to box:

The assault stopped me turning pro. It was my dream. So, I went through all the usual, feeling suicidal, you know, I didn't have anything. It sounds dead shambolic but until that happened... I was living with a Page 3 Girl [glamour model] and had a Sierra Cosworth [sports car]. You know, I was living the lifestyle; sports cars and fighting at the top level, then when that happened, it was just like hmmmm. I hit rock bottom. I went back.

From the above excerpt we can see that the "assault" (that Tyrone never explicitly names), removed the artefacts that surrounded his identity as a boxer, and this is what arguably contributed towards his suicidal feelings. Winlow and Hall (2009) argue that

\footnotetext{
2 Ricky Hatton, the previous Welterweight champion of the world, described suicidal thoughts after a threeyear absence from the ring when he suffered a crushing defeat in the defence of his title.
} 
feelings of humiliation, particularly among working class men, can contribute towards violent behaviour and thoughts, and they posit that events that are perceived as humiliating can powerfully influence the individual's perception of their place in the social order.

Everyday life for Tyrone became about "replaying the event in my head", disclosing that he went over ever possible scenario of both triumph and complete avoidance in relation to the attack. To "get out of his own head", Tyrone practiced standing every day, and eventually after six months, coupled with a visit from his old boxing coach, he managed to walk again. Partially sighted from the blow to the head, Tyrone was still classed as disabled, but with encouragement from his trainer he managed to start running to "get his weight back down". While being self-conscious about "being fat again" and also having flashbacks of the attack, Tyrone admittedly was struggling to cope. Nonetheless, being able to walk again, and the subsequent re-sculpting of his body had given Tyrone's confidence a boost. It was only now that he felt he was getting "back to his old self", having lost some weight, and regained the physical capital to rebuild his sense of self and identity.

The attack was still in the forefront of Tyrone's mind, and as much as he had "let it go and didn't have a go back at them", I got the impression it was still a psychological painful experience for him. Moreover, having lost "the car and the girl", Tyrone felt his personal worth had been devalued, therefore, his way of gaining some form of control was to recondition his body back into a carapace of muscle. Winlow and Hall (2009) argue that the internalisation of personal worth within a capitalist framework is inextricably linked to the acquisition and ornamentation of consumer culture. For Tyrone, the loss of both "car and girl" was a dent to his cultural worth in a working-class milieu that places emphasis on the adornment of masculine artefacts. Artefacts that demonstrate wealth and virility are of particular worth to those that place value on masculine accomplishment through visible means, therefore, the loss of both "car and girl" would accumulate to a devastating blow. Tyrone thus honed his physical capital back into a threatening structure to alleviate feelings of vulnerability and a potential loss of cultural standing, as the failure to deal with the assault contributed to Tyrone's loss and humiliation. As a result of the non-retaliation, Tyrone's image as the local hard lad was a distant memory, and the replaying of the event served as torture to Tyrone, who in the eyes of others had failed to display localised forms of both cultural and symbolic capital.

\section{6. "Getting back in the game"}

When talking with Tyrone about his sense of self before the assault, he described his body as "amazing", and "like a machine", whereas he described feeling "worthless" after the attack. He was, however, determined to return to his prior fitness, as he described his state of mind at the time of peak fitness as "dream like" and similar to "floating". Furthermore, Tyrone discussed finding a "sense of calm" in physical workouts and this was something he wished he could feel again:

There's a lot of people who are aggressive, that can be in your face, I worked out hard every morning, making me feel calm and relaxed, so there was nothing people could do to make me rise, I need to get back to that. 
From this above statement it is fair to assume that Tyrone finds a sense of security in his own physicality, not just in terms of outward appearance but against his own persecutory anxiety. Tyrone used his body as a defence mechanism, and the feeling of "floating" that occurs at times of supreme fitness may be indicative of a psychological transcendence as opposed to a purely physical one. The "sense of calm" that Tyrone suggests, is presumably more around the calmness of mind that he feels when he is in control of his body. Reinforcing the concept of physical capital as a signifier of social standing, Tyrone bases his argument for exercising as an external motivation. I felt that Tyrone liked himself more when he felt worthy, and this in turn acted as an external locus for positive affirmation. For example, if Tyrone did not see himself as the "fat kid" then that made it easier for others to not seen him as that either. "Being liked", or feeling worthy of someone's admiration started to become apparent in Tyrone's narrative, as he discussed how he got "back in the game", with the help from his trainer. The visit from his old trainer while in the wheelchair encouraged Tyrone, and as a result, he felt able to return to the world of amateur boxing. Tyrone was convinced the coach had "his best interests at heart", and began running and regaining his fitness in line with the coach's requests. Unable to enter any professional tournaments due to the blood clot on his brain, Tyrone gave up the idea of being "a top pro", and instead focused on local competitions. With further encouragement from his coach, Tyrone went on to win the next 29 local amateur bouts, and gained the media's attention that were interested in writing a local success story. Moreover, Tyrone's subsequent victories started to generate interest amongst the local boxing fraternity, and thus, a "big fight" was organised to showcase Tyrone and his story.

\section{The "big fight"}

On the night of the fight, Tyrone's trainer and his new girlfriend's son were there to help him in his corner. Tyrone's new girlfriend had wanted her son to take up boxing, and Tyrone had invited him along to his "big fight" to give him a "taste of things to come". A television company was also present that night, and Tyrone felt "confident"; "look who's laughing now", as he described his comeback after the assault, he "was in it to win it". Unfortunately for Tyrone, so was his opponent. Tyrone described that night as his "big comeback", but disclosed feeling nervous and self-conscious, especially as a result of all the media attention. He knew the worst thing that could happen to him would be to "get knocked out", and therefore admitted to entering the ring "more determined than ever to win":

You train to win. That's it. I entered the ring that night not wanting to be knocked out, losing is ok, but it's a pride thing about not wanting to be knocked down. And when there's loads of people there, high profile people, you know, TV companies and newspapers and all that, and I just didn't want to lose, and he obviously didn't want to lose either.

Both men lost that night as the referee stopped the fight. Tyrone ended up in hospital with internal bleeding and Tyrone's opponent died a few minutes after the final bell. I asked Tyrone what happened, and told me how he had an "unbelievable desire to win that night" and "wouldn't back down" when he knew he was hurt.

I ended up fighting when I knew I should have stopped, we did 'toe to toe' which doesn't happen anymore, and I ended up with internal bleeding and he died. 
Tyrone was still visibly shaken when talking of this event, and I could tell he wanted to move the conversation forward so as not to get upset. It transpired that his opponent was his friend, and they had fought many times before on a friendly level. Also, the fact that the fight was being recorded and his trainer and girlfriend's son were in his corner contributed towards Tyrone feeling like he had something to prove. Additionally, this was the first time Tyrone had invited the local community to spectate as he felt that this was his "big comeback fight", thus, he felt that the "pressure was on". What that pressure meant to Tyrone is complex; on one hand there was the pressure to "put on a show for the TV cameras", and at a deeper, more personal level, I argue there was a further pressure to reaffirm his sense of identity as the "local hard man with a heart of gold". Conversely, what propelled Tyrone was not a heart of gold, but a burning desire to reaffirm his masculine status - his gender capital - in the eyes of others, and disavow any sense of victimization and vulnerability that may have been bestowed upon him by the significant male protagonists in both his family and his community.

James Gilligan $(1996,61)$ writes of violence as "symbolic action", and to therefore understand violence, we must reverse the procedure and learn to "interpret action as symbolic language". In the case of Tyrone, this would certainly make sense. Moreover, Messner (1990) amongst others (Atyeo 1979, Sabo 1986) discusses how winning in sport is usually predicated on the successful utilisation of violence, and that the human body is routinely used as a weapon against others in sporting events. On this particular night, defined as his "big comeback", Tyrone entered the ring with an agenda. I do not think Tyrone intentionally killed his opponent, but I would argue that the added pressure of having an audience of his peers present encouraged him to continue fighting against his own better judgement. This is not uncommon, as many athletes in the pursuit of winning will endanger their health, and Vaz (1980) and Smith (1974) argue that those athletes who use excessive force in their craft often gain higher levels of status than those who stick within their limits. According to Bredemeier (1983), competition in the rule-bound structure of sport is a major basis for men's relationships with the world, and therefore aggression "within the rules" is often considered legitimate and safe. Tyrone justified his opponent's death within this structure by stating that "someone who boxes knows the risks", and "shit like that happens from time to time".

As much as I could sense that Tyrone genuinely felt remorseful for what happened that night, I felt that he justified his opponent's death as part of the game. When probing Tyrone further, he revealed that he carried on boxing that night because he was "just trying to be the best at something", and it was with this latter statement that I felt Tyrone had a deeper investment in his comeback than first anticipated. "Trying to be the best" clouded Tyrone's judgement that night, and I felt this was part of a larger discourse in masculine sports that sanctions the use of violence in the pursuit of winning. Messner $(1990,98)$ states that "individual's roles and separate positions within hierarchies are determined by competition within a clearly defined system of rules which govern the interactions of participants", and for Tyrone that night, winning became more important than death.

\section{Memory, retaliation, and male violence}

Generally speaking, in psychodynamic terms, to understand current behaviours and thinking patterns you must first explore the past. Hence, revisiting the truth of an event 
becomes a crucial process in grasping the essence of the now. Freud (1995) suggested that in order to truly to move on from a painful event one must summon up the courage to remember it correctly, and to deny or distort the truth forms part of a complex defence mechanism in warding off feelings of anxiety. In Tyrone's case, I felt the memory of the assault was a driving factor in Tyrone's present behaviour, and I would argue that the attack was on his mind during the night of the big fight. The fact that Tyrone never retaliated against his assailants, nor fully admitted the extent of his humiliation, led me to believe that the assault was "replaying in his head" before stepping into that ring. Having previously argued that the majority of working-class men are driven by a code, or guided by a habitus where retaliation is expected and valued, I would argue that Tyrone, in full presence of his peers, had the perfect opportunity to regain his status.

The big "comeback" was Tyrone's opportunity to renegotiate his subject position from victim of attempted murder ${ }^{3}$ back to "local hard lad" and successful boxer. I would argue that Tyrone displaced his humiliating defeat at the hands of his assailants by brutally going "toe to toe" with his opponent. Dispelling his better judgement under the guise of desperately "not wanting to be knocked out", Tyrone managed to displace his aggression onto his rival. He found a safer target for his aggression that allowed him to resolve his emotional fragility, and offer a sense of closure with an idealised image of himself. Indeed, Winlow and Hall (2009) argue that when we transport ourselves back to painful memories, the painful reality is often manifested beneath a host of images, feelings and scenarios, constructed to transform the painful event into one that is less shameful and/or humiliating. Seen in this way, it is possible to recall in the mind what we would have liked to occur as opposed to what actually happened. Accordingly, we think not of how we actually responded to the event, but in the ways in which we would have liked to respond. As a result, these thought processes can serve as defence mechanisms that can sublimate ignominious defeat into heroic triumph (ibid.). In Tyrone's case, it was a way to regain status and identity as a boxer, while helping to eradicate the shame and humiliation that the original event created. Moreover, the "big fight" acted as an arena for Tyrone's emotional displacement, without the risk posed to his family, and it became instrumental in Tyrone overcoming feelings of shame for not having retaliated earlier. By successfully reproducing a situation in which he could rectify his image in front of a community that had previously seen him fail, Tyrone was able to regain his status as the local boxer and also local hardman. ${ }^{4}$

Violence provides a framework for notions of respect (Neff et al. 1991, Butler and Maruna 2009), and this is vastly important to men like Tyrone. Men who have been subjected to previous violent attacks, and also inhabit daily environments where violence is an acceptable solution to a problem. This is not uncommon, and work by Wolfgang (1959), Luckenbill (1977), Katz (1988) and Toch (1992), among others, suggests that violence is a compensatory measure when certain individuals feel their identity is under threat; in particular, individuals who have been sensitized to shame (Gilligan 1996). Gilligan theorizes that violent self-images, images that are underpinned by self-narratives, are constructed by feelings of shame and insecurity. He proposes that violent men tend to

\footnotetext{
${ }^{3}$ The police report classified the assault as attempted murder, yet to this day not a single person has been charged.

${ }^{4}$ Tyrone informed me that he retired from boxing completely that night. He never set foot back in the ring as a boxing contender.
} 
summon and engage in violent physical altercations as a way to defend against the psychological anxiety of being shamed and humiliated. This, in turn, restores feelings of power and control to the self, and rectifies the self-imagery that one will not tolerate disrespect and the shame that coexists. For Tyrone, the shame of repeat victimization was so abhorrent, that he would do everything in his power to avoid any future recourse. Therefore, violence forms part of most boxer's cultural make-up, a strategy and a resource in maintaining respect and avoiding shame. Boxing contributes towards this maintenance and avoidance. It forms part of the strategy that allowed Tyrone to not only employ its physical benefits in the maintenance of his "respectful" reputation, but also proved useful in his ability to legally "comeback", after a humiliating assault.

Katz $(1988,24)$ in his work around "righteous slaughter" discusses the concept of how one "transcends into rage" when feelings of humiliation arise: "[A] loss of control over one's identity may seem irremediable when injury has been inflicted on one's public image; image and reputation is social and therefore, outside one's personal control"'. This is symbolic not only in terms of reinforcing one's masculine status, but also provides a method of directing one's anger. Humiliation can also be a contributory factor in the instigation of violence (Katz 1988), as it not only provides a reason to "transcend into rage" (ibid.), but can further lead to feelings of shame and guilt. Scheff (1994) discusses shame as a feeling similar to humiliation, and defines it as an emotion that somehow judges our sense of decency, particularly in the eyes of others. Furthermore, it is seen in contrast to pride, and raises the kind of self-consciousness that results from the judgement of oneself through the eyes of others, and the night of the big comeback fight, all eyes were on Tyrone.

\section{Conclusion}

Using Tyrone as an example, it is clear to see that physical capital is not just part of a system in which men use their bodies to accumulate wealth and status. Somatic power and the ability to demonstrate one's violent potential is also an underlying factor in the appeal of boxing for men like Tyrone. The old adage, "it takes a certain kind of person to get hit for fun", certainly chimes with this story, and many others like Tyrone. That certain person is usually a vulnerable young man, who, under the pressures of prior victimization, either by bullies in the local community, or men armed with metal wheel braces, shows up at a boxing gym with a desire to prevent any repeat victimization.

As Winlow and Hall (2009) suggest, the ways in which men direct their anger at inanimate objects (and sometimes other men) are not just about feelings of anger and injustice, but also because of their retrospective dissatisfaction at prior performances. They argue that men's perceived futures are somewhat bleak when they have previously demonstrated passivity, and this can lead to cultural irrelevance and loss of status. The punching of walls, or even punch-bags, is a common transference of repressed aggression, and I argue that the actual blows thrown that night are the ones that Tyrone wished he had been able to throw at the night of the attack. In Tyrone's case, the opportunity to wrestle back his perceived dignity came at a large prize. However, for Tyrone, I got the impression it was worth it. To be left without closure on a painful experience was too much to bear for him, and the cultural messages from his "tough working-class area" further enhanced Tyrone's feelings of shame and emotional disturbance at his own passivity. As a result, the "big fight" became less about a 
"comeback" for Tyrone, and more about eradicating the "shit in his head", while simultaneously reinstating his sense of identity and pride after a loss.

Stripped of any ability to retaliate due to being in a wheelchair, Tyrone was arguably able to rectify his image in the eyes of others through refusing to back down on the night of the big fight, even against his own better judgement. The stakes were too high. Tyrone had to prove to himself and others that his legacy as a man of latent power and violent potential had not been lost, and that the assault was a one-off; he was the one "laughing now!" Boxing, as well as creating this legacy, also helps to sustain it, and the transcendence that pugilists describe when their physical capital is at its peak is as much about psychological control as it is somatic power. Connell $(1995,53)$ posits that "bodily experience is often central in memories of our own lives, and thus in our understanding of who and what we are". For men like Tyrone, they not only view their bodies as maps of experience, but also as signifiers of both physical and gendered social capital. These signifiers become vastly important for men like Tyrone, as they not only serve as defense mechanisms in environments that value shows of strength, but also contribute towards accruing respect and status for those in possession of both.

\section{References}

Anderson, E., 1999. Code of the Street: Decency, Violence, and the Moral Life of the Inner City. New York: Norton.

Atyeo, D., 1979. Blood \& Guts: Violence in Sports. New York: Grosset \& Dunlap.

Blok, A., 1981. Rams and Billy Goats: A Key to the Mediterranean Code of Honour. Royal Anthropological Institute of Great Britain and Ireland [online], 16(3), 427-440. Available from: https://doi.org/10.2307/2801293 [Access 25 September 2020].

Bourdieu, P., 1984. Distinction: A Social Critique of the Judgement of Taste. Trans.: R. Nice. London: Routledge.

Bourdieu, P., 1986. The Forms of Capital. In: J.G. Richardson, ed., Handbook of Theory and Research for the Sociology of Education. New York: Greenwood Press, 241-258.

Bredemeier, B.J., 1983. Athletic aggression: A moral concern. In: J.H. Goldstein, ed., Sports Violence. New York: Springer, 47-81.

Bridges, T.S., 2009. Gender capital and male bodybuilders. Body $\mathcal{E}$ Society [online], 15(1), 83-107. Available from: https://doi.org/10.1177/1357034X08100148 [Access 25 September 2020].

Brown, D., 1999. Male Bodybuilders and the Social Meaning of Muscle, Auto/Biography, 7(1-2), 83-90.

Butler, M., 2008. What are you looking at? Prisoner confrontations and the search for respect. The British Journal of Criminology [online], 48(6), 856-873. Available from: https://doi.org/10.1093/bjc/azn053 [Access 25 September 2020].

Butler, M., and Maruna, S., 2009. The Impact of Disrespect on Prisoner's Aggression: Outcomes of Experimentally Inducing Violence-Supportive Cognitions. Psychology, Crime and Law [online], 15(2-3), 235-250. Available from: https://doi.org/10.1080/10683160802190970 [Access 25 September 2020]. 
Connell, R.W., 1995. Masculinities. Cambridge: Polity Press.

Connell, R.W., 1998. Reply. Gender E Society [online], 12(4), 474-7. Available from: https://doi.org/10.1177/089124398012004009 [Access 25 September 2020].

Crocker, J., et al., 2003. Contingencies of self-worth in college students: theory and measurement. Journal of personality and social psychology [online], 85(5), 894. Available from: https://doi.org/10.1037/0022-3514.85.5.894 [Access 25 September 2020].

Ellis, A., Winlow, S., and Hall, S., 2017. “Throughout my life I've had people walk all over me": Trauma in the lives of violent men. The Sociological Review [online], 65(4), 699-713. Available from: https://doi.org/10.1177/0038026117695486 [Access 25 September 2020].

Freud, S. (with P. Gay, ed.), 1995. The Freud Reader. New York: WW Norton \& Company.

Fussell, S., 1991. Muscle: Confessions of an Unlikely Bodybuilder. New York: Poseidon Press.

Gadd, D., 2004. Making sense of interviewee-interviewer dynamics in narratives about violence in intimate relationships. International Journal of Social Research Methodology [online], 7(5), 383-401. Available from: https://doi.org/10.1080/1364557092000055077 [Access 25 September 2020].

Gilligan, J., 1996. Violence: Our Deadly Epidemic and its Causes. New York: GP Putnam.

Hall, S., 1997. Visceral Cultures and Criminal Practices. Theoretical Criminology [online], 1(4), 453-78. Available from: https://doi.org/10.1177/1362480697001004003 [Access 25 September 2020].

Hobbs, D., 1995. Bad Business. New York: Oxford University Press.

Jefferson, T., 2002. Subordinating hegemonic masculinity. Theoretical criminology [online], 6(1), 63-88. Available from: https://doi.org/10.1177/136248060200600103 [Access 25 September 2020].

Jump, D., 2020. The Criminology of Boxing, Violence and Desistance. Bristol: Policy Press.

Katz, J., 1988. Seductions of Crime: The Moral and Sensual Seductions of Doing Evil. New York: Basic Books.

Klein, A.M., 1986. Pumping Iron: Crisis and Contradiction in Bodybuilding. Sociology of Sport [online], 3(2), 112-133. Available from: https://doi.org/10.1123/ssj.3.2.112 [Access 25 September 2020].

Luckenbill, D.F., 1977. Criminal Homicide as a Situated Transaction. Social Problems [online], 25(2), 176-86. Available from: https://doi.org/10.2307/800293 [Access 25 September 2020].

Maruna, S., and Matravers, A., 2007. N=1: Criminology and the person. Theoretical Criminology [online], 11(4), 427-442. Available from:

https://doi.org/10.1177/1362480607081833 [Access 25 September 2020]. 
Matthews, C., 2014. Biology Ideology and Pastiche Hegemony. Men and Masculinities [online], 17(2), 99-119. Available from: https://doi.org/10.1177/1097184X14526699 [Access 25 September 2020].

McAdams, D.P., 1993. The Stories We Live By: Personal Myths and the Making of the Self. New York: Guilford Press.

Merton, R. K., 1938. Social structure and anomie. American sociological review [online], 3(5), 672-682. Available from: https://doi.org/10.2307/2084686 [Access 25 September 2020].

Messner, M.A., 1990. When Bodies Are Weapons: Masculinity and Violence in Sport. International Review for the Sociology of Sport [online], 25(3), 203-220. Available from: https://doi.org/10.1177/101269029002500303 [Access 25 September 2020].

Neff, J.A., Prichoda, T.J., and Hoppe, S.K., 1991. Machismo, Self-Esteem, Educational and High Maximum Drinking Among Anglo, Black and Mexican American Male Drinkers. Journal of Studies on Alcohol [online], 52(5), 458-463. Available from: https://doi.org/10.15288/jsa.1991.52.458 [Access 25 September 2020].

Oates, J.C., 1987. On Boxing. London: Bloomsbury.

Robins, D., and Cohen, P., 1978. Knuckle Sandwich. Harmondsworth: Penguin.

Sabo, D., 1986. Pigskin, Patriarchy and Pain. In: M. Messner and D. Sabo, Sex, Violence and Power in Sports: Rethinking Masculinity. Freedom: Crossing Press, 82-88.

Scheff, T.J., 1994. Bloody Revenge: Emotions, Nationalism, and War. Boulder: Westview Press.

Scheff, T.J., 2000. Shame and the Social Bond. Sociological Theory [online], 18(1), 84-99. Available from: https://doi.org/10.1111/0735-2751.00089 [Access 25 September 2020].

Sennett, R., and Cobb, J., 1973. The Hidden Injuries of Class. New York: Vintage.

Shilling, C., 1993. The Body and Social Theory. London/Newbury Park: Sage.

Smith, M.D., 1974. Significant Others' Influence on the Assaultive Behavior of Young Hockey Players. International Review of Sport Sociology [online], 9(3), 45-58.

Available from: https://doi.org/10.1177/101269027400900303 [Access 25 September 2020].

Theberge, N., 1991. Reflections on the Body in the Sociology of Sport. Quest [online], 43. Available from: https://doi.org/10.1080/00336297.1991.10484017 [Access 25 September 2020].

Toch, H., 1992. Violent Men: An Inquiry into the Psychology of Violence. Revised ed. Washington, DC: American Psychological Association.

Vaz, E.W., 1980. The Culture of Young Hockey Players: Some Initial Observations. In:

D. Sabo and R. Runfola, eds., Jock: Sports and Male Identity. Englewood Cliffs: Prentice Hall. 
Wacquant, L., 1995. Pugs at Work: Bodily Capital and Bodily Labour Among Professional Boxers. In: C.L. Cole, J. Loy and M.A. Messner, eds., Exercising Power: The Making and Remaking of the Body. Albany: State University of New York Press.

Wiley, R., 1989. Serenity: A Boxing Memoir. New York: Henry Holt and Company.

Winlow, S., 2001. Badfellas: Crime, Tradition and New Masculinities. Oxford: Berg.

Winlow, S., and Hall. S., 2009. Retaliate First: Memory, Humiliation and Male Violence. Crime, Media, Culture [online], 5(3), 285-304. Available from: https://doi.org/10.1177/1741659009349243 [Access 25 September 2020].

Wolfgang, M.E., 1959. Patterns in Criminal Homicide. New York: John Wiley and Sons.

Young, J., 2003. Merton with Energy, Katz with Structure: The Sociology of Vindictiveness and the Criminology of Transgression. Theoretical Criminology [online], 7(3), 389-414. Available from: https://doi.org/10.1177/13624806030073007 [Access 25 September 2020]. 